\title{
Recenzja: Zbyszko Melosik, Pitka nożna. Tożsamość, kultura i władza, WN UAM, Poznań 2016
}

Kolejna książka Zbyszko Melosika nie będzie czytana jedynie przez fanów piłki nożnej, choć przede wszystkim to pewnie oni sięgną po tę pozycję. To książka dla wszystkich, którzy lubią rozmyślać nad społeczną różnorodnością identyfikacji społecznych, nad sposobami konstruowania tożsamości kolektywnej, nad budowaniem własnego świata przylgnięć aksjologicznych (perspektywa jednostkowa), a z drugiej strony nad wzorami kultury i sposobami dyfuzji treści kulturowych, w tym sportu (perspektywa społeczna). Autor pozycji przyzwyczaił już swoich czytelników do świeżych metafor i ciekawych analogii odnoszących się do kultury i tożsamości. Wprowadzone przez Niego we wcześniejszych dziełach terminy, takie jak „globalny nastolatek”, „kultura instant” czy też „tożsamość typu all inclusive” (tożsamość typu przezroczystego) (Melosik 2004: 69-95; 2007: 73-90) na stałe weszły do dyskursu pedagogicznego i socjologicznego, wzbogacając heurystyczny warsztat pojęć współczesnego naukowca pochylającego się nad hiperkonsumpcyjną rzeczywistością późnej nowoczesności. Po raz kolejny przenikliwe ostrze analizy (krytyki, afirmacji) kieruje autor w kierunku globalnej praktyki społecznej, tym razem jest to gra w piłkę nożną oraz bycie jej fanem, które to zjawisko śpiesznemu obserwatorowi jawi się co najwyżej jako fenomen ludyczny, hedonistyczny, a czasami biznesowy (wszak piłka nożna stała się dziś przemysłem). 0 tym, jak wiele treści, znaczeń, praktycznych wniosków potrafił wyciągać autor z opisywanych przez siebie we wcześniejszych publikacjach zachowań zbiorowych, takich jak bycie na diecie (Melosik 1996: 100-171), kulturystyka, seksturystyka, sięganie po viagrę (Melosik 2002) itp. przekonało się już kilka pokoleń studentów oraz reprezentantów dyscypliny pedagogika, dla których spostrzeżenia Melosika precyzyjnie strukturalizowały myślenie o edukacji nieformalnej, roli tożsamości człowieka w podejmowaniu codziennych wyborów, władzy ukrytej w dominujących dyskursach kulturowych. Czy piłka nożna i kibicowanie odzwierciedlają jakieś interesują-

\footnotetext{
* Uniwersytet Śląski w Katowicach.
} 
ce i ważkie kwestie społeczne? Czy zakres znaczeniowy tych pojęć (zjawisk) wykracza poza kategorię czasu wolnego oraz konstatację, że jest to najpopularniejszy sport na świecie? Czy istnieje jeszcze jakieś znaczenie, które powinno wejść w definiens futbolu?

Autorowi udało się pokazać, że w sporcie tym ogniskuje się wiele problemów społecznych, takich jak: względność/przejściowość tego co elitarne oraz tego co masowe (piłka niegdyś vs dzisiejszy futbol), obecność w życiu społecznym momentów zawieszenia podziałów społecznych aktualizujących równość społeczną i egalitaryzm (brak stratyfikacji społecznej na trybunach i możliwość dokonania awansu społecznego przez piłkarzy z underclass na wyżyny sławy i bogactwa), potęga procesów globalizacji/kolonizacji, które narzucają innym kulturom obce praktyki społeczne, ale i możliwość glokalnej akulturacji tych praktyk (w istocie brytyjski wynalazek, jakim jest piłka nożna, został przyswojony, ale i przekształcony przez argentyński czy brazylijski charakter narodowy), aporie wielu zjawisk społecznych, w tym także sportu (wydarzenia piłkarskie jako wyraz narodowej dumy, ale i kompleksów; piłka nożna bywa elementem wysokiego kapitału kulturowego, przedmiotem zainteresowania yuppies oraz narzędziem socjalizacji elit, jak w USA, a z drugiej strony jest główną aktywnością podejmowaną przez młodzież z gett socjalnych, narzędziem emancypacji kobiet oraz awansu społecznego, np. Maradona).

Futbol to nie tyle pole męskiej alienacji, ale przede wszystkim, co pokazuje w swojej książce Zbyszko Melosik, ważny towar eksportowy wielu nacji (zwłaszcza Argentyny i Brazylii), ważne źródło tożsamości narodowej - towar często zawłaszczany przez polityków dla uprawomocnienia swojej władzy. Futbol to reifikacja męskości. Tezy powyższe wysuwają się na plan pierwszy refleksji podjętej przez autora w rozdziale pierwszym i drugim.

W rozdziale trzecim Autor obrazuje przemiany kulturowe zachodzące od kilkudziesięciu lat w Japonii, której rdzeń kulturowy opiera się w coraz mniejszym stopniu na wartościach kolektywnych, a coraz częściej na indywidualizmie. Nieudana próba odniesienia futbolowego sukcesu na arenie międzynarodowej przez Japończyków doskonale odzwierciedla kłopot Japonii z wartościami Zachodu; wartościami gwarantującymi efektywność futbolu (nastawienie na sukces, parcie do przodu, inicjatywa własna i dopiero na koniec współpraca zespołowa).

Dowodem na to, że komentowanie stosunku do piłki nożnej określonej społeczności, zamieszkującej określoną szerokość geograficzną, jest dla Zbyszko Melosika pretekstem do szerszych analiz społeczno-kulturowych - co nie wyklucza czystej fascynacji autora fenomenem gry w piłkę, która daje się dostrzec w całej analizowanej publikacji - jest rozdział czwarty poświęcony relacjom futbolu amerykańskiego do piłki nożnej (soccer). Stosunek Amerykanów do piłki nożnej jawi się jako klasyczny resentyment, czyli niechęć do tego, czego samemu nie jest się w stanie do końca skonsumować. Amerykanie dobrze wyczuwają, że na tym polu nie mają szans rywalizować z krajami europejskimi czy południowoamery- 
kańskimi. Zresztą mają swój własny sport, który lepiej oddaje ich charakter narodowy - ofensywny, dynamiczny i nigdy niegodzący się na zgniły kompromis w postaci remisu. Futbol amerykański daleko lepiej zagospodarował pragnienia i potrzeby narodu amerykańskiego niż piłka nożna, wynalazek dawnego kolonizatora z Anglii. Niechętny stosunek Amerykanów do piłki nożnej jest dla autora wyrazem obawy tego narodu, ale i jego inteligencji, która karze mu widzieć w tym sporcie utrudnienie dla procesu asymilowania się wielu mniejszości narodowych wchodzących w skład społeczeństwa amerykańskiego. Piłka nożna w USA pozostaje - jak zauważa autor - sportem imigrantów łączącym Amerykanów z wielu grup mniejszościowych z ich grupą etniczną i krajem swojego pochodzenia. Te i inne dociekania autora doskonale obrazują amerykańską tożsamość, wpisane w nią lęki i aspiracje.

W rozdziale piątym autor pokazuje z kolei, jak styl gry (nadbudowa) warunkowany jest charakterem narodowym i przestrzenią geograficzną (bazą) kraju. Finezja holenderskiego futbolu, jak nigdzie indziej, koresponduje z architekturą miast oraz ze sposobem pozyskiwania (zdobywania) terenu do gry (egzystencji) w ograniczonej przestrzeni boiska (kraju). Wypracowany przez Holendrów styl gry („totalnego futbolu”) jawi się jako konieczny warunek odnoszenia przez nich sukcesów sportowych, a odejście od niego jest przyczyną odnoszenia licznych klęsk przez „pomarańczową drużynę”.

Rozdział szósty traktuje o piłce niemieckiej. I ponownie w przekonujący sposób autor dowodzi narodowotwórczego charakteru piłki nożnej. Sukcesy niemieckiej piłki przez całe dziesięciolecia od ukończenia II wojny światowej leczyły niemieckie kompleksy i lęki związane z eksponowaniem swojej wyjątkowości, dumy i wielkości; zwycięstwa drużyny niemieckiej uprawomocniały na nowo posługiwanie się emblematami narodowymi (hymn, flaga). Przy okazji wątku niemieckiego autor publikacji dzieli się z czytelnikami - co wydaje się musiało nastąpić w kontekście nieobojętnego stosunku autora do piłki nożnej - własną satysfakcją wypływającą z gry polskich zawodników w lidze niemieckiej (Błaszczykowski, Piszczek, Lewandowski). Jest to w mojej opinii ważny i ciekawy wątek, ponieważ w całości pracy autor nie poświęcił więcej miejsca polskiej piłce nożnej. Szkoda, ponieważ z pewnością byłaby to bardzo ciekawa część książki - w końcu nie brakuje nad Wisłą narodowych kompleksów, dla których balsamem było w ostatnim czasie dotarcie do ćwierćfinału Mistrzostw Europy, a teraz są sukcesy polskich skoczków narciarskich.

Ostatni rozdział (siódmy) autor poświęcił rozważaniom wokół żeńskiej piłki nożnej. Ta wciąż budząca kontrowersje aktywność kobiet pełni - jak zauważa autor - różne funkcje w społeczeństwie. Z jednej strony jest czynnikiem emancypacji kobiet, negacją stereotypowego, mizoginistycznego, pełnego uprzedzeń podejścia do ról kobiecych, z drugiej jednak strony organizatorzy turniejów żeńskiej piłki nożnej, ale także same piłkarki nierzadko uczestniczą w procesie wzmacniania konwencjonalnego wizerunku kobiecości jako obiektu - jak metafo- 
rycznie, ale trafnie ujmuje to Melosik - inwazyjnego i pełnego pożądania spojrzenia męskiego oka.

Rekapitulując, należy podkreślić, że nową publikację Zbyszko Melosika czyta się lekko i z zaintrygowaniem. Przy lekturze nieobecne jest - przynajmniej z mojej męskiej perspektywy czytelniczej - znużenie terminologią socjologiczną, ponieważ przywoływane reminiscencje dotyczą żywotnej pasji konsumowania piłki nożnej. Bycie fanem to aktywność autoteliczna, dla której nie trzeba szukać żadnych uzasadnień, choć jak pokazuje Zbyszko Melosik, nie brakuje szerokiego kontekstu przyczyn, dla których społeczeństwa przywiązują tak dużą wagę do tego sportu. Zaskakujące, ale i oryginalne zarazem jest odkrycie, że futbol może mieć tak różne oblicza, konteksty, genezę w zależności od szerokości geograficznej, w której jest celebrowany. Zbyszko Melosik wydobywa głębię z aktywności, która wydawałoby się jest jej pozbawiona. Gorąco polecam czytelnikom lekturę tej książki.

\section{Bibliografia}

Melosik Z. (1996) Tożsamość, ciało i władza. Teksty kulturowe jako (kon)teksty pedagogiczne, Poznań-Toruń, Wydawnictwo Edytor.

Melosik Z. (2002) Kryzys męskości w kulturze współczesnej, Poznań, Wydawnictwo Wolumin.

Melosik Z. (2004) Kultura popularna jako czynnik socjalizacji w: Pedagogika. Podręcznik akademicki, Z. Kwieciński, B. Śliwerski (red.), t. 2, Warszawa, Wydawnictwo Naukowe PWN.

Melosik Z. (2007) Teoria i praktyka edukacji wielokulturowej, Kraków, Oficyna Wydawnicza „Impuls”. 